\title{
Tema d'anàlisi:
}

\author{
Educar, què és?*
}

\section{Aportació de Dr. Octavi Fullat}

\section{Advertiment al voltant del mot 'educació'}

El senyor Mariano Rajoy, Cap del Govern de I'Estat Espanyol, fa ús del terme diàleg. En grec dia fou "a través de" i logos significà "discurs raonat";

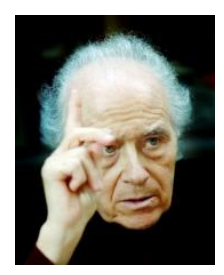

Dr. Octavi Fullat

C Filòsof de l'educació. Catedràtic Emèrit de la Universitat Autònoma de Barcelona dia-logar consistia en una activitat mental en la qual la raó progressava per mitjà de l'un i de l'altre en un joc honrat d'anar i venir a fi d'elaborar un concepte -allò concebut de què resten amarats els interlocutors- amb el qual avenir-se. Els Diàlegs platònics consistiren en aquest esforç i no pas en una altra cosa.

S'esdevé que el senyor Mariano emet el so diàleg a tall de tic nerviós o de moviment convulsiu com altres obren $\mathrm{i}$ tanquen les parpelles o mouen el cap sovint sense adonar-se'n. Heus ací! i no hi ha res més. Le Cours de linguistique générale del lingüista suís Ferdinand de Saussure (1857-1913) mostrà que la parla —llengües i llenguatges - compta amb paraules, les quals cal capir des dels components: el significant -o bé fònic o bé gràfic-, el significat imatge cerebral vinculada amb el

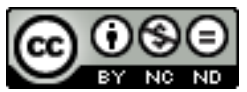

significant- i, per fi, el referent realitat extramental a la qual s'adreça-.

Emprar el significant educació tot ignorant el seu significat constitueix una barbaritat, un acte forassenyat, groller, incult. Ara bé; no és fàcil concretar el significat dels termes dels quals es valen llengües i llenguatges - adverteixo que no es tracta de sinònims-. La parla, cada cop menys, avança amb naturalitat. Està sotmesa a pressions dels diversos poders socials: polítics, econòmics, eclesiàstics, tecnocientífics, artístics, laborals. Sota aquesta tibantor sociolingüística la parla va perdent la seva dimensió comunicativa. Acabarà essent tan sols agregació d'interjeccions que ens llençarem els uns contra els altres?, els mots reduïts a projectils verbals o escrits? En què acabarà aleshores l'ésser humà?

Aquest succint article o col•laboració no ambiciona cap altra cosa que no sigui això: apropar-se al significat del mot educació.

\section{Punt zero del procés educador: la "Physis"}

Pocs seran els qui neguin que l'ésser humà pertany a la Natura. Entre d'altres coses a causa que tothom menja i evacua o així ens ho sembla. Vivim des 
de la nostra manera de sentir-nos en el món.

Els grecs clàssics, els nostres preclars predecessors, denominaren Physis a allò que els llatins anomenaren després Natura i nosaltres hem batejat amb el terme Naturalesa. El vocable physis té origen en el verb phyo - "produir", "engendrar", "fer créixer" —. La physis, per a aquell antic grec, fou l'ambit en el qual es produeix tot, unes coses provenint d'altres inclosos els déus. Aquesta producció era eterna i, per tant, sobrava la figura del Creador.

El grup humà es resultat de filogènesi o evolució. Cada individu del grup concreta l'evolució amb el seu codi genètic, el qual porta informació que s'executarà bioquímicament.

L'herència biològica s'objectiva al cervell. L'anatomia i la fisiologia del sistema nerviós condicionen poderosament les funcions somàtiques i psíquiques de cada subjecte.

L'herència genètica programa cada cervell, que posa en marxa les glàndules endocrines que segregen hormones, substàncies químiques que exciten els ritmes funcionals. La neuroendocrinologia dóna explicació dels fenòmens psicosomàtics com emocions, memòria, agressivitat, sexualitat, set, fam...

L'ésser humà, per començar, és ineludiblement cos, sarx-cos orgànic- en grec, carn viva. El cos humà difereix del cos de les altres bèsties pel fet que ens col-loca davant la realitat mentre que el dels animals es limita a rebre estímuls i a respondre-hi.
S'esdevé que la programació genètica no programa pas totes les conductes humanes posibles; en aquest punt fa aparició la necessitat de la programació social. Els animals constitueixen sistemes closos; l'ésser humà, en canvi, és un sistema obert que s'esforça a tancar-se a base de produir civilització.

D'ençà del moment en què han aparegut comportaments -sabers i activitats- que el codi genètic humà no programa, no queda més remei que aprendre els de la civilització on un hom es troba instal•lat, si pretén sobreviure.

La natura no planteja el tema del sentit o significació; en canvi, la història - tota civilització és històrica- demana pel sentit viu del per a què. L'anthropos, a més de passat i de present, viu també del futur, que encara no hi és.

\section{Factor imprescindible del procés educador: la "Polis".}

La història s'aparta de la natura en tant que aquesta resta configurada per un sistema constant de referències -les lleis naturals-, mentre que aquella, la història, consisteix en constant avenç obert cap a allò nou.

En tota civilització podem distingir tres àmbits: símbols o cultura -maneres de veure el món-, tècniques -maneres de modificar el món o Umwelt, que és el medi circumstant - i, per últim, institucions socials -maneres col•lectives d'instal•lar-se en el món-.

Gràcies al símbol, l'ésser humà s'allibera de restar inexorablement enganxat a l'entorn, al context —Umwelt-; aquest fet el distingeix de la resta natural. 
L'home viu la circumstància lingüísticament, amb símbols, els quals no són el món, sinó que en fan esment. Entre el sistema receptor d'estímuls i el sistema emissor de respostes, nosaltres hem col-locat el sistema simbòlic o cultural. Entre l'aigua de la font i la meva set, hem interposat paraules. El món real se'ns redueix a formes simbòliques amb les quals l'organitzem mentalment.

Però, no tan sols entenem el món, sinó que, a més, el modifiquem tot tractantlo tècnicament. L'ésser humà s'ha apropiat de la natura, per exemple, amb l'agricultura, l'urbanisme, la terapèutica. La revolució microelectrònica de la fi del segle XXè constitueix el darrer salt tecnològic i ha portat l'electrònica digital.

D'altra banda, l'anthropos s'instal•la col•lectivament en el món. La parla, a part de ser estructura lingüística, és igualmente fenomen social de comunicació. Hom parla a d'altri. Et parlo a tu. Sense un tu, no existeix el jo. La comunicació obre la comunidad.

Les societats històriques cada cop estan més carregades d'institucions. Al paleolític eren mínimes. En l'actualitat ens depassen.

L'herència biològica resulta insuficient per a tirar endavant en l'existència; cal aprendre la cultura, les tècniques i les institucions d'una civilització. És quan apareixen els processos educatius d'aprenentatge -learning-. L'ésser humà és animal educandum, animal que ha d'educar-se si vol esdevenir home. El sistema psicoorgànic és inacabat; la civilització el conclou històricament. Els processos educatius transmeten el món que l'ésser humà ha fabricat.

Tot individu humà és el resultat del genoma sotmès a transaccions amb el medi no humà —processos maduratius - i a transaccions amb el medi humà - processos educatius d'aprenentatge- El learning es duu a terme en transmetre informacions, desvetllant actituds i bastint hàbits; només així s'ingressa a la civilització.

Estimo que els models constructivistes, como el de Piaget, inspirat en Kant, són los models més acceptables a fi de comprendre els processos educatius d'aprenentatge.

\section{Element desmesurat o metacientífic de l'educació: "Eleuteria" o, si un cas, "Ruah".}

L'educació entesa com a aprenentatge és un procés programat per altres, pels que no són l'educand, sinó que són els situats al costat dels educadors. Cal demanar-se: resta alguna escletxa perquè qui s'educa sigui, en algun moment $\mathrm{i}$ en algun àmbit, senyor de la seva educació? La meva resposta és positiva per bé que confesso que li manca cientificitat; es tracta d'una aposta, quasi penja tan sols de la decisió volitiva.

Acte de consciència personal, acte de llibertat i capacitat de projectar-se són tres experiències que la persona humana pot tenir i que duen a plantejar-se que alguna cosa pot donarse més enllà d'allò provat científicament. Si hom parteix de les Filosofies de la Consciència —Descartes, 
Husserl...- en comptes de dur-ho a terme tot partint exclusivament de les Filosofies de I'Estructura - Saussure, Lévi-Strauss... - resulta possible d'imaginar que l'ésser humà disposa de la capacitat de ser autos —ell mateix-.

Únicament acceptant aquest plantejament resulta possible pensar en valors de l'educació que frueixin de consistència $\mathrm{i}$ no es redueixin a valors fàctics d'una societat o d'un individu valors socials i valors psíquics-.

Amb la present perspectiva neix la possibilitat que al costat de les educacions-aprenentatge es puguin col-locar les educacions-alliberadores. Per això resulta imprescindible que, a més de comptar amb la Naturalesa i la Civilització, suposem que existeix I'Esperit Conscient. La moral autònoma, que disposa de consistència, no viu de la raó, sinó de la llibertat responsable.

L'animal humà és un animal problemàtic que mai no suprimeix els seus problemes, tan problemàtic és que la raó no pot explicar-lo del tot.

Comptem sens dubte amb educacióaprenentatge; pot ser, a més, que disposem d'educació-alliberadora.

\section{Bibliografia}

Fullat, O.: Antropologia filosòfica de l'educació.

Nota: aquesta obra conté abundant bibliografia

*Versió traduïda de l'espanyol 